\title{
The Effect of Solar Proton Events on Ozone and Other Constituents
}

\author{
Charles H. Jackman and Richard D. McPeters
}

NASA Goddard Space Flight Center, Greenbelt, Maryland.

\begin{abstract}
Solar proton events (SPEs) can cause changes in constituents in the Earth's middle atmosphere. The highly energetic protons cause ionizations, excitations, dissociations, and dissociative ionizations of the background constituents. Complicated ion chemistry leads to $\mathrm{HO}_{x}$ production and dissociation of $\mathrm{N}_{2}$ leads to $\mathrm{NO}_{\mathrm{y}}$ production. Both the $\mathrm{HO}_{\mathrm{x}}$ and $\mathrm{NO}_{\mathrm{y}}$ increases can result in changes to ozone in the stratosphere and mesosphere. The $\mathrm{HO}_{\mathrm{x}}$ increases lead to short-lived ozone decreases in the mesosphere and upper stratosphere due to the short lifetimes of the $\mathrm{HO}_{\mathrm{x}}$ constituents. The $\mathrm{NO}_{\mathrm{y}}$ increases lead to long-lived stratospheric ozone changes because of the long lifetime of $\mathrm{NO}_{\mathrm{y}}$ constituents in this region. The $\mathrm{NO}_{\mathrm{y}}$-induced ozone changes are generally decreases, however, the $\mathrm{NO}_{\mathrm{y}}$ constituents can interfere with chlorine and bromine radicals in the lowest part of the stratosphere and cause ozone increases. Temperature changes have been predicted to occur as a result of the larger SPEs. Atmospheric changes have been observed as a result of eleven SPEs since 1969. Neutral wind variations were measured shortly after the July 1982 and April 1984 SPEs. The recent July 2000 SPE caused $\mathrm{NO}_{x}$ increases that lasted for two months past the event. The two periods of largest SPEs (August 1972 and October 1989) caused ozone decreases that lasted for several weeks past the events.
\end{abstract}

\section{INTRODUCTION}

Periodically, the Sun erupts in a solar flare and an associated coronal mass ejection (CME) that results in an intense flux of solar particles in interplanetary space. The solar particles from a CME can impact the Earth's magnetosphere if the location of the Earth is aligned relative to the solar flare and the solar magnetic field (see Figure 1). This is known as a solar proton event (SPE). The sunward side of the magnetosphere is further flattened from the norm and the tail is additionally elongated. Most particles are then drawn in on the far side of the magnetosphere and are carried into the polar cap regions (generally $>60^{\circ}$ geomagnetic latitude).

Solar Variability and its Effects on Climate

Geophysical Monograph 141

This paper not subject to U.S. copyright

Published in 2004 by the American Geophysical Union

10.1029/141GM21
The eruptions of solar protons, which are more frequent near solar maximum, can produce ionizations, dissociations, dissociative ionizations, and excitations in the middle atmosphere. The very important middle atmospheric families of $\mathrm{HO}_{\mathrm{x}}\left(\mathrm{H}, \mathrm{OH}, \mathrm{HO}_{2}\right)$ and $\mathrm{NO}_{\mathrm{y}}\left(\mathrm{N}, \mathrm{NO}, \mathrm{NO}_{2}, \mathrm{NO}_{3}\right.$, $\mathrm{N}_{2} \mathrm{O}_{5}, \mathrm{HNO}_{3}, \mathrm{HO}_{2} \mathrm{NO}_{2}, \mathrm{ClONO}_{2}, \mathrm{BrONO}_{2}$ ) are produced either directly or through a photochemical sequence. As a result, the chemistry of the polar middle atmosphere (stratosphere and mesosphere) can be dramatically altered by large solar proton events.

There has been proof that the Sun can produce significant fluxes of highly energetic particles for about 60 years [Forbush, 1946]. A large SPE that occurred over 30 years ago in November 1969 gave the first evidence that ozone could be depleted by these solar eruptions [Weeks et al., 1972]. The influence of SPEs on the atmosphere has matured over the years and evidence of impacts by at least 


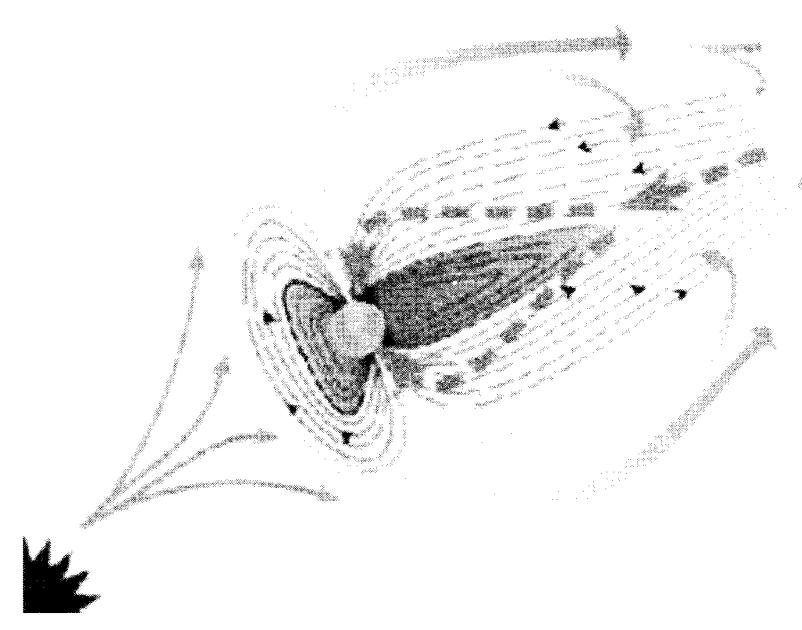

Figure 1. Schematic indicating the Earth and associated magnetosphere interacting with solar particles from a CME. The CME resulted from an explosion on the Sun (lower left corner) and caused further flattening of the sunward side of the magnetosphere and additional elongation of the tail. This was taken from an image on the CDROM entitled "The Dynamic Sun 4.0" from the NASA/ESA Solar and Heliospheric Observatory (SOHO) Mission.

11 large events (see Table 1) is well documented in the refereed literature and will be discussed below.

Other energetic charged particles, besides solar protons, also have an influence on the Earth's atmosphere. Auroral electrons primarily influence the thermosphere and upper part of the mesosphere with associated bremsstrahlung penetrating to the upper and middle stratosphere. Relativistic electrons primarily influence the mesosphere and upper part of the stratosphere, although their associated bremsstrahlung can reach the middle to lower stratosphere. These electrons are influenced by the Earth's magnetic field and affect the subauroral region (geomagnetic latitudes between $60^{\circ}$ and $70^{\circ}$ ). Galactic cosmic rays (GCRs) deposit most of their energy in the lower stratosphere and upper troposphere. These very high energy particles are not as affected by the Earth's magnetic field and the higher energy GCRs can influence all the way to tropical latitudes.

Solar protons, which primarily impact the mesosphere and stratosphere, are affected by the Earth's magnetic field and deposit most of their energy in the polar cap regions $\left(>60^{\circ}\right.$ geomagnetic latitude). Like electron precipitation events, the solar proton influences can be sporadic and impulsive. The very highest energy solar protons $(>100$ $\mathrm{MeV}$ ) can influence the middle to lower stratosphere, a region also affected by the lower energy GCRs. There are similarities in the atmospheric influences among all precip- itating charged particles, e.g., most of the energy deposited in the atmosphere results in ionizations. There are also differences in the temporal characteristics of the particular events and the spatial influences (both altitude and latitude regions). The details of the differences among these precipitating charged particles is beyond the scope of this review and we will only focus on the effects of the solar protons.

This paper is divided into seven primary sections, including the introduction. We discuss the very important solar proton measurements in section 2. Knowledge of the solar proton flux is crucial in computing the atmospheric impacts. The solar protons produce both $\mathrm{HO}_{\mathrm{x}}$ and $\mathrm{NO}_{\mathrm{y}}$ constituents, which are discussed in sections 3 and 4, respectively. The impact of the SPEs on ozone is discussed in section 5 and the temperature and dynamical changes from SPEs are discussed in section 6. Finally, the conclusions are given in section 7 .

\section{SOLAR PROTON MEASUREMENTS}

Solar protons have been measured by several satellites over the past few decades. The Interplanetary Monitoring Platform (IMP) series of satellites has provided measurements from 1963 to the present. The IMP satellites are in orbits that position them in interplanetary space most of the time. The last of these satellites, IMP-8, launched on October 26, 1973, is in a near circular, 35 Earth radii, 12day orbit. The NOAA Geostationary Operational Environmental Satellites (GOES) have provided measurements since 1975. The GOES series of satellites are in geosynchronous orbits at about $35,800 \mathrm{~km}$ above the Earth. These IMP and GOES satellite orbits, far from the Earth's atmosphere, provide reliable measurements of incoming solar protons.

The solar proton flux can change dramatically within a matter of minutes and primarily influences the polar regions. The temporal characteristics and spatial influence of the solar protons will be discussed in the next two subsections.

\subsection{Temporal Characteristics}

The solar proton flux is generally quite small for protons with sufficient energy to penetrate into the middle atmosphere. However, SPEs can bring significant fluxes of protons in the near Earth environment, which can influence the middle atmosphere. Although SPEs can occur at anytime during the eleven year solar cycle, more SPEs happen near solar maximum. The October 1989 SPEs, which produced the highest flux of solar protons in the past thirty years, showvery large changes in proton fluxes over a short period 
Table 1. List of solar proton events (SPEs) and measured atmospheric constituent influence documented in the literature. The effects on ozone were all decreases and the effects on $\mathrm{NO}$ and $\mathrm{NO}_{2}$ were all increases. This is not an exhaustive list of publications and other references are given later for particular SPEs.

\begin{tabular}{|c|c|c|}
\hline Date of SPEs & Effects of SPEs & Publication(s) \\
\hline November 1969 & Ozone & Weeks et al. [1972] \\
\hline January 1971 & Ozone & McPeters et al. [1981] \\
\hline September 1971 & Ozone & McPeters et al. [1981] \\
\hline August 1972 & Ozone & Heath et al. [1977], also others \\
\hline June 1979 & Ozone & McPeters and Jackman [1985] \\
\hline August 1979 & Ozone & McPeters and Jackman [1985] \\
\hline October 1981 & Ozone & McPeters and Jackman [1985] \\
\hline July 1982 & $\begin{array}{l}\text { Ozone, } \\
\text { NO }\end{array}$ & $\begin{array}{c}\text { Ozone in Thomas et al. [1983], also others; } \\
\text { NO in McPeters [1986] }\end{array}$ \\
\hline December 1982 & Ozone & McPeters and Jackman [1985] \\
\hline October 1989 & $\begin{array}{l}\text { Ozone, } \\
\mathrm{NO} \\
\mathrm{NO}_{2}\end{array}$ & $\begin{array}{c}\text { Ozone in Reid et al. [1991], also others; } \\
\mathrm{NO} \text { in Zadorozhny et al. [1992]; } \\
\mathrm{NO}_{2} \text { in Jackman et al. }[1995]\end{array}$ \\
\hline July 2000 & $\begin{array}{l}\text { Ozone, } \\
\mathrm{NO}, \mathrm{NO}_{2}\end{array}$ & $\begin{array}{l}\text { Ozone in Jackman et al. [2001]; } \\
\mathrm{NO} \& \mathrm{NO}_{2} \text { during event in Jackman et al. [2001]; } \\
\mathrm{NO} \& \mathrm{NO}_{2} \text { after event in Randall et al. [2001] }\end{array}$ \\
\hline
\end{tabular}

of time. The protons with energies from 4.2 to $8.7 \mathrm{MeV}$, which deposit most of their energy between about 75 and 85 $\mathrm{km}$, increased their flux by about a thousand in minutes (see Figure 2). Ultimately, the increase in proton flux was five orders of magnitude above background in a couple of hours.

\subsection{Spatial Influence}

Higher energy protons deposit their energy lower in the atmosphere. The precipitating protons primarily lose their energy in the creation of ion pairs in the atmosphere. An ion pair is created when a precipitating proton removes an electron (called a secondary electron) from the neutral molecule or atom, leaving behind a positive ion. The protons impart energy on the secondary electrons and these freed charged particles also cause further ionizations in the atmosphere. A computation of the rate of ionizations by incoming monoenergetic protons and their associated electrons is given in Figure 3. These protons have a flux of $1 \mathrm{~cm}^{-2} \mathrm{~s}^{-1} \mathrm{ster}^{-1}$ and are isotropic in distribution. Approximately $35 \mathrm{eV}$ is expended in the production of an ion pair [Porter et al., 1976]. The total ionization rate for an SPE is computed using the actual particle spectrum multiplied by the individual monoenergetic deposition values.

Because of the guiding influence of the Earth's magnetic field, the effects are generally confined to the polar regions and have their largest influence on the regions of the polar caps, defined as the northern and southern areas with latitudes greater than about $60^{\circ}$ geomagnetic. The impact of the very large July 2000 SPE on mesospheric ozone is illustrated in Plate 1. This plate shows the NOAA $14 \mathrm{SBUV} / 2$ ozone measurements for the $0.5 \mathrm{hPa}(\sim 55 \mathrm{~km})$ level [Jackman et al., 2001]. The plot on the left indicates ozone amounts on July 13, before the SPE. The plot on the right indicates ozone amounts on July 14-15, during the maximum intensity of the SPE. The polar cap $\left(>60^{\circ}\right.$ geomagnetic) is outlined by the thick white oval. This plate illustrates the very significant changes in ozone during the SPE that are generally confined to the polar cap. The ozone reduction slightly outside the polar cap near $90^{\circ} \mathrm{E}$ longitude is probably caused by the Earth's magnetic field being perturbed somewhat during this very large solar disturbance. The ozone in the area outside the polar cap region did not change significantly from July 13 to July $14 / 15$.

The atmospheric influence of a SPE is dependent on the energy spectrum of the solar protons and the absolute flux levels at the particular energies. The August 1972 SPEs were the second largest in the past 30 years and caused very significant atmospheric effects (discussed later). The computed ionization rates for these very large SPEs are given in Figure 4.

The largest values of ionization rate were computed to occur within several hours after the onset of these SPEs, and were caused by the highest energy protons. These SPEs were very "hard spectrum" events with a huge flux of very energetic protons. These fast moving protons (with energies greater than $30 \mathrm{MeV}$ ) arrived first and dominated the first several hours of these SPEs (Figure 4). These particular 


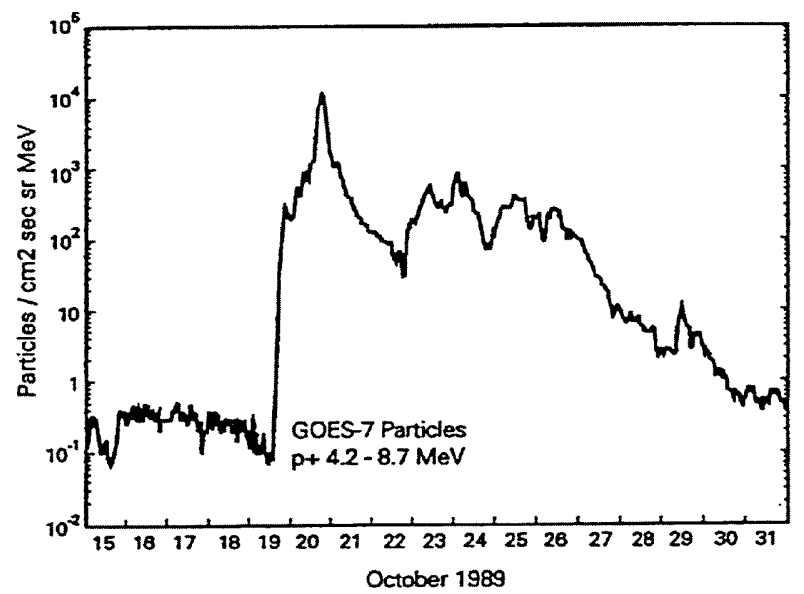

Figure 2. The solar proton flux (E=4.2-8.7 MeV) from GOES-7 for the second half of October 1989. Reprinted from J. Atmos. Terr. Phys., 54, A. M. Zadorozhny, G. A. Tuchkov, V. N. Kikhtenko, J. Lastovicka, J. Boska, and A. Novak, Nitric oxide and lower ionosphere quantities during solar particle events of October 1989 after rocket and ground-based measurements, 183-192, Fig. 1, Copyright(1992), with permission from Elsevier Science.

SPEs had computed ionization rates of over $1000 \mathrm{~cm}^{-3} \mathrm{~s}^{-1}$ for over a day with peak ion rates over $40000 \mathrm{~cm}^{-3} \mathrm{~s}^{-1}$ in the stratosphere $(\sim 10-50 \mathrm{~km})$. Not all SPEs cause such large ion pair production in the stratosphere and, in general, most large SPEs induce atmospheric changes primarily in the mesosphere $(\sim 50-90 \mathrm{~km})$.

\section{PRODUCTION OF $\mathrm{HO}_{\mathrm{X}}$ CONSTITUENTS BY SPES -MODEL COMPUTATIONS}

Precipitating protons also produce $\mathrm{HO}_{\mathrm{x}}$ constituents. The basic theory for the $\mathrm{HO}_{\mathrm{x}}$ production by these particles has been known for the past thirty years. Solomon et al. [1981] provide a clear analysis of the current understanding of this process. Some earlier papers that discussed this process are Swider and Keneshea [1973] and Frederick [1976]. The production of $\mathrm{HO}_{\mathrm{x}}$ relies on complicated ion chemistry that takes place after the initial formation of ion pairs.

The production of the original positive ions $\mathrm{N}_{2}{ }^{+}, \mathrm{O}_{2}{ }^{+}, \mathrm{N}^{+}$, and $\mathrm{O}^{+}$depends on the efficiency for production from both the primary protons and their associated electrons. The $\mathrm{O}_{2}{ }^{+}$ constituent has a smaller ionization potential than $\mathrm{N}_{2}{ }^{+}, \mathrm{N}^{+}$, or $\mathrm{O}^{+}$, thus most ions rapidly charge exchange to form it. $\mathrm{NO}^{+}$, also a potential source of odd hydrogen [Solomon et al., 1981], is formed when $\mathrm{N}^{+}$and $\mathrm{O}^{+}$atoms react with $\mathrm{O}_{2}$ and $\mathrm{N}_{2}$, respectively. The oxonium ion $\left(\mathrm{O}_{4}^{+}\right)$is generally formed from $\mathrm{O}_{2}{ }^{+}$via the path

$$
\mathrm{O}_{2}^{+}+\mathrm{O}_{2}+\mathrm{M} \rightarrow \mathrm{O}_{4}^{+}+\mathrm{M}
$$

Water cluster ions are then formed via

$$
\mathrm{O}_{4}^{+}+\mathrm{H}_{2} \mathrm{O} \rightarrow \mathrm{O}_{2}^{+} \cdot \mathrm{H}_{2} \mathrm{O}+\mathrm{O}_{2}
$$

Further clustering follows this reaction with an ultimate recombination between the positive ion and an electron or negative ion. The shortest path leading to $\mathrm{HO}_{\mathrm{x}}$ production is given by:

$$
\begin{aligned}
& \mathrm{O}_{2}{ }^{+} \cdot \mathrm{H}_{2} \mathrm{O}+\mathrm{H}_{2} \mathrm{O} \rightarrow \mathrm{H}_{3} \mathrm{O}^{+} \cdot \mathrm{OH}+\mathrm{O}_{2} \\
& \mathrm{H}_{3} \mathrm{O}^{+} \cdot \mathrm{OH}+\mathrm{e}^{-} \rightarrow \mathrm{H}+\mathrm{OH}+\mathrm{H}_{2} \mathrm{O} \\
& \text { Net: } \mathrm{H}_{2} \mathrm{O} \rightarrow \mathrm{H}+\mathrm{OH} .
\end{aligned}
$$

Solomon et al. [1981] discuss other paths for $\mathrm{O}_{2}{ }^{+} \cdot \mathrm{H}_{2} \mathrm{O}$, which lead to $\mathrm{HO}_{\mathrm{x}}$ production through recombination with free electrons. The negative ions (especially $\mathrm{NO}_{3}^{-}$) become more abundant than the free electrons below about $70 \mathrm{~km}$. A possible path in this region is:

$$
\begin{aligned}
& \mathrm{O}_{2}{ }^{+} \cdot \mathrm{H}_{2} \mathrm{O}+\mathrm{H}_{2} \mathrm{O} \rightarrow \mathrm{H}_{3} \mathrm{O}^{+} \cdot \mathrm{OH}+\mathrm{O}_{2} \\
& \mathrm{H}_{3} \mathrm{O}^{+\cdot} \mathrm{OH}+\mathrm{H}_{2} \mathrm{O} \rightarrow \mathrm{H}^{+\cdot} \cdot\left(\mathrm{H}_{2} \mathrm{O}\right)_{2}+\mathrm{OH} \\
& \mathrm{H}^{+\cdot} \cdot\left(\mathrm{H}_{2} \mathrm{O}\right)_{2}+\mathrm{NO}_{3}{ }^{-} \rightarrow \mathrm{HNO}_{3}+\mathrm{H}_{2} \mathrm{O}+\mathrm{H}_{2} \mathrm{O} \\
& \mathrm{HNO}_{3}+\mathrm{hv} \rightarrow \mathrm{OH}+\mathrm{NO}_{2} \\
& \text { Net: } \mathrm{H}_{2} \mathrm{O}+\mathrm{NO}_{3} \rightarrow \mathrm{OH}+\mathrm{OH}+\mathrm{NO}_{2} .
\end{aligned}
$$

Either this path or a similar one takes place in the region where negative ions prevail. The number of $\mathrm{HO}_{\mathrm{x}}$ constituents produced per ionization as a function of altitude and ionization rate is shown in Figure 5 for daytime, polar

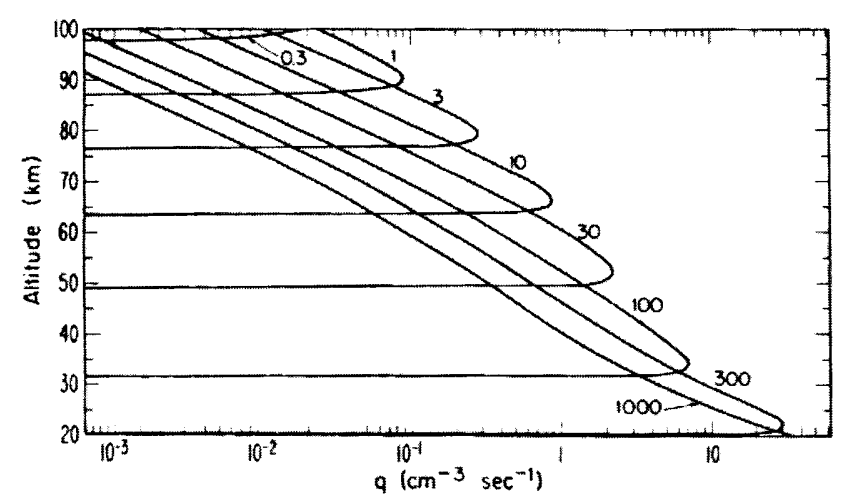

Figure 3. Rate of production of ion pairs in the atmosphere by monoenergetic fluxes of protons incident isotropically over the upward-looking hemisphere with a flux of 1 proton $\mathrm{cm}^{-2} \mathrm{~s}^{-1} \mathrm{ster}^{-1}$. Curves are for energies from $0.3 \mathrm{MeV}$ to $1000 \mathrm{MeV}$. Reprinted from Kluwer Academic Publishers book Physics of the Sun, Vol. III, edited by P. A. Sturrock, pp. 251-278, Chapter 12 - Solar energetic particles and their effects on the terrestrial environment, $\mathrm{G}$. C. Reid, Fig. 1, 1986, with kind permission from Kluwer Academic Publishers. 

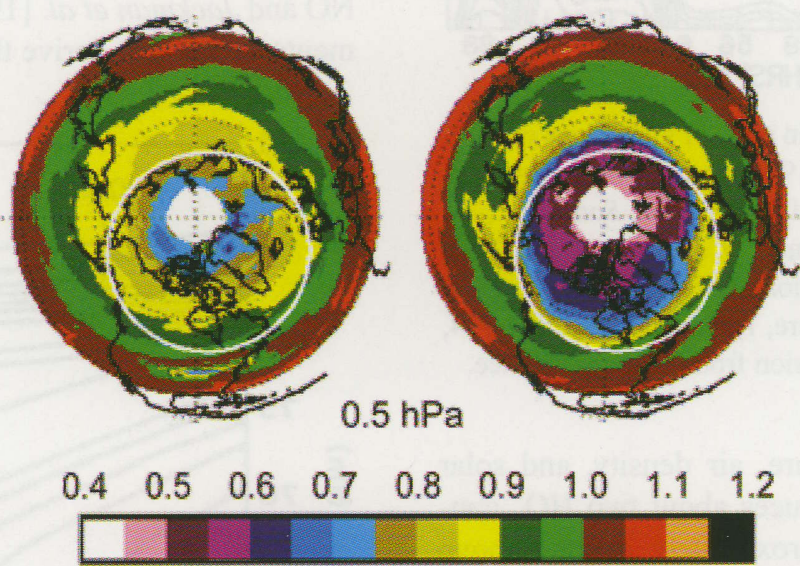

Mixing Ratio (ppmv)

Plate 1. Taken from Fig. 1 of Jackman et al. [2001]. NOAA 14 SBUV/2 Northern Hemisphere polar ozone in ppmv before (July 13, 2000) and during (July 14/15) the solar proton event period at $0.5 \mathrm{hPa}(\sim 55 \mathrm{~km})$. The white circle indicates the boundary at $60^{\circ} \mathrm{N}$ geomagnetic, above which solar protons can penetrate to the Earth's atmosphere. 


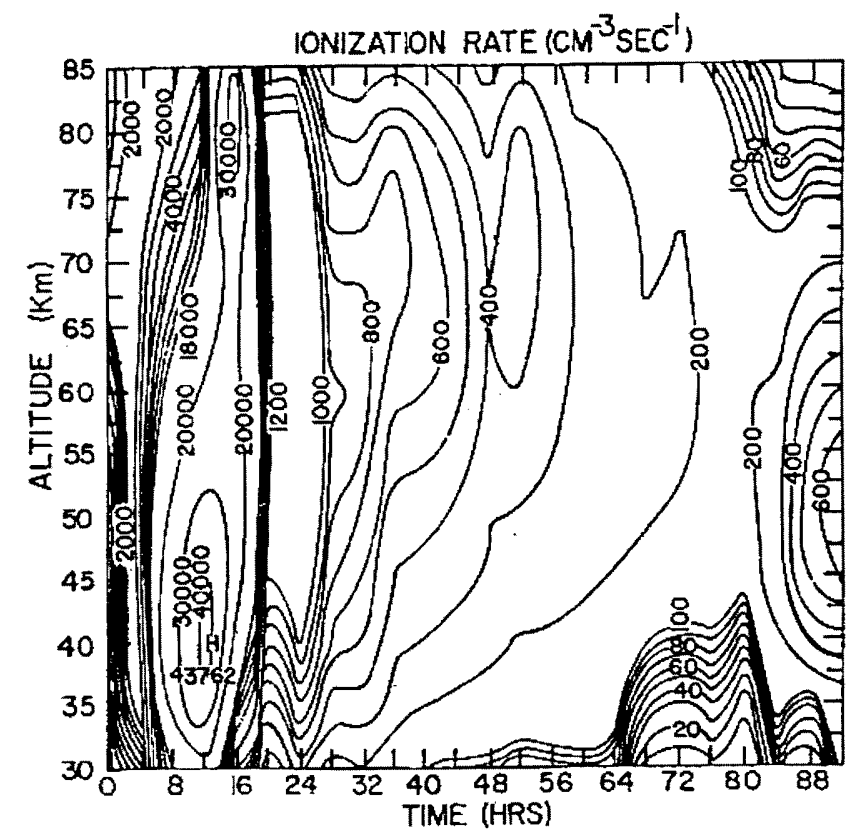

Figure 4. Contours of ionization rate in units of ionizations $\mathrm{cm}^{-3} \mathrm{~s}^{-1}$ for the first four days of the August 1972 proton events. Time 0 is August 4, 1972, at 339 U.T. Reprinted from Planet. Space Sci., 29, Rusch, D. W., J.-C. Gerard, S. Solomon, P. J. Crutzen, and G. C. Reid, The effect of particle precipitation events on the neutral and ion chemistry of the middle atmosphere, 1, Odd nitrogen, 767-774, Fig. 4, Copyright(1981), with permission from Elsevier Science.

summer conditions of temperature, air density, and solar zenith angle. Each ion pair produces about two $\mathrm{HO}_{\mathrm{x}}$ constituents up to an altitude of approximately $70 \mathrm{~km}$. Above $70 \mathrm{~km}$, the production is less than two $\mathrm{HO}_{\mathrm{x}}$ constituents per ion pair [Solomon et al., 1981]. As the ionization rate increases the computed electron density increases and the probability of the recombination of the intermediate positive ions with the electrons or negative ions increases. Thus at all altitudes the number of $\mathrm{HO}_{\mathrm{x}}$ constituents produced per ion pair is seen to decrease with ionization rate. The production of the $\mathrm{HO}_{\mathrm{x}}$ constituents produced per ion pair is not very dependent on solar zenith angle and will be as effective at night as during the daytime.

The $\mathrm{HO}_{\mathrm{x}}$ constituents react fairly quickly to destroy each other through reactions like

$$
\mathrm{OH}+\mathrm{HO}_{2} \rightarrow \mathrm{H}_{2} \mathrm{O}+\mathrm{O}_{2}
$$

Therefore, the lifetime of $\mathrm{HO}_{\mathrm{x}}$ is only on the order of hours in the upper stratosphere and mesosphere. Any corresponding change in the atmosphere caused by the $\mathrm{HO}_{\mathrm{x}}$ species would only last for a couple of hours past any SPE (see section 5.1).
Large changes in $\mathrm{HO}_{\mathrm{x}}$ constituents have been computed to result from SPEs. For example, during the July 2000 SPE, $\mathrm{HO}_{\mathrm{x}}$ was computed to increase by over $100 \%$ [Jackman et al., 2001] at sunrise. To the best of our knowledge there are no published measurements of $\mathrm{HO}_{\mathrm{x}}$ changes during SPEs. Such measurements would be extremely useful to validate the theory of the $\mathrm{HO}_{\mathrm{x}}$ production during SPEs.

\section{PRODUCTION OF NO CONSTITUENTS BY SPES}

All SPEs produce $\mathrm{NO}_{\mathrm{y}}$, however, the SPE-caused $\mathrm{NO}_{\mathrm{y}}$ enhancement has only been measured as a result of the three very large SPEs that occurred in July 1982, October 1989, and July 2000 (Table 1). These SPEs all showed substantial $\mathrm{NO}$ and/or $\mathrm{NO}_{2}$ increases. McPeters [1986] used Nimbus 7 SBUV measurements to derive NO increases during the July 1982 SPE. Zadorozhny et al. [1992] used rockets for NO and Jackman et al. [1995] employed SAGE II measurements for $\mathrm{NO}_{2}$ to derive the influences of the October 1989

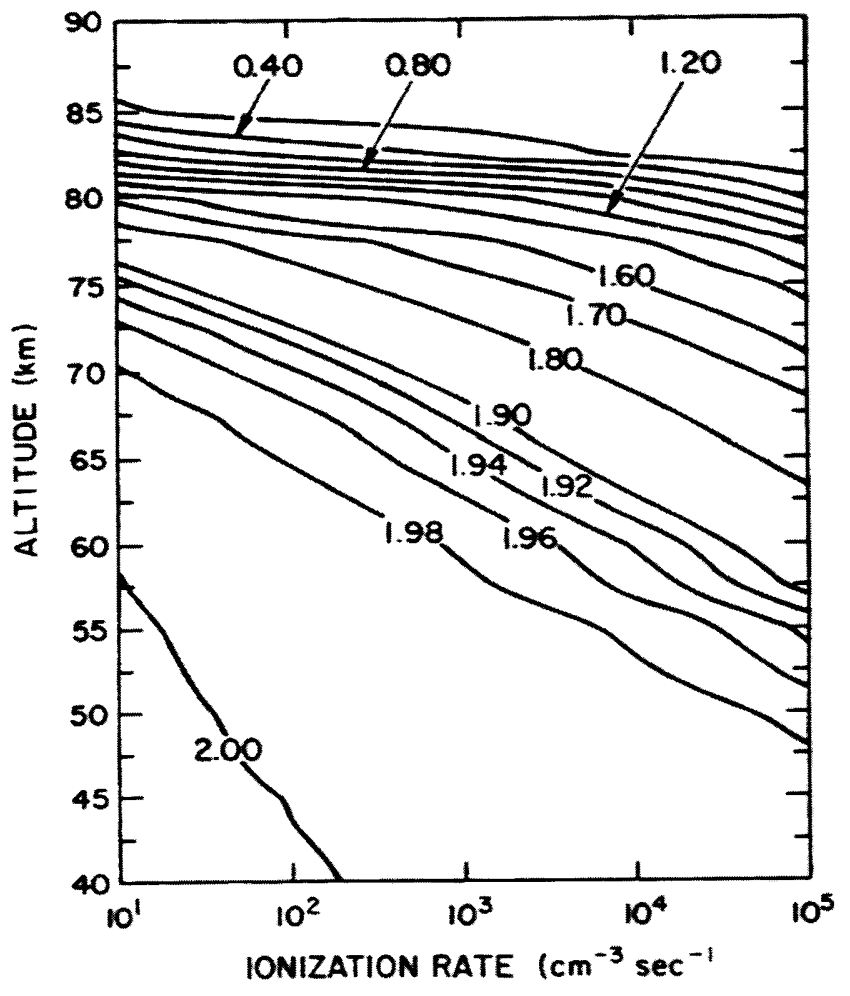

Figure 5. Contours of odd hydrogen particles produced per ionization as a function of altitude and ionization rate for daytime summer polar conditions. Reprinted from Planet. Space Sci., 29, S. Solomon, D. W. Rusch, J.-C. Gerard, G. C. Reid, and P. J. Crutzen, The effect of particle precipitation events on the neutral and ion chemistry of the middle atmosphere, 2, Odd hydrogen, 885-892, Fig. 2, Copyright(1981), with permission from Elsevier Science. 
SPEs on $\mathrm{NO}_{\mathrm{y}}$. Jackman et al. [2001] and Randall et al. [2001] used the Upper Atmosphere Research Satellite (UARS) HALOE instrument data to establish the July 2000 SPE increases in $\mathrm{NO}_{\mathrm{x}}\left(\mathrm{NO}+\mathrm{NO}_{2}\right)$. The influence of SPEs on $\mathrm{NO}_{\mathrm{y}}$ in the atmosphere through both measurements and model simulations will be discussed in this section.

\subsection{Measurements and Model Computations of SPE- caused $\mathrm{NO}_{y}$}

The precipitating protons and associated secondary electrons also produce atomic nitrogen $(\mathrm{N})$ via dissociations, predissociations, or dissociative ionizations in collisions with $\mathrm{N}_{2}$. Estimates of the number of $\mathrm{NO}_{\mathrm{y}}$ constituents created per ion pair range from 0.33 [Warneck, 1972] up to 2.5 [Fabian et al., 1979]. Recent publications show only small differences and range from 1.25 [Jackman et al., 1990] up to 1.3 [Reid et al., 1991] $\mathrm{NO}_{\mathrm{y}}$ constituents produced per ion pair.

The production of $\mathrm{NO}_{y}$ by SPEs has been predicted since the mid-1970s [Crutzen et al., 1975]. The NO increase after the July 1982 SPE was inferred from the Nimbus 7 SBUV instrument to be about $6 \times 10^{14} \mathrm{NO}$ molecules $\mathrm{cm}^{-2}$ above 1 $\mathrm{hPa}$ at polar latitudes [McPeters, 1986]. Jackman et al. [1990] computed an NO increase of $7 \times 10^{14}$ above $1 \mathrm{hPa}$ from the July SPE using an assumption that all the $\mathrm{NO}_{\mathrm{y}}$ produced during this SPE resulted in the production of NO. Zadorozhny et al. [1992] measured NO enhancements of $2.6 \times 10^{15} \mathrm{~cm}^{-2}$ between 50 and $90 \mathrm{~km}$ at southern polar latitudes with a rocket-borne instrument as a result of the October 1989 SPEs. Jackman et al. [1995] computed a production of $\mathrm{NO}$ in that altitude range of $3.0 \times 10^{15} \mathrm{~cm}^{-2}$, again assuming all the $\mathrm{NO}_{y}$ produced during these October 1989 SPEs resulted in the production of NO. Both of these computations are in reasonable agreement but higher than the measurements because some of the NO would be destroyed in the daytime through the reactions

$\mathrm{NO}+\mathrm{h} v \rightarrow \mathrm{N}+\mathrm{O}$

followed by $\mathrm{N}+\mathrm{NO} \rightarrow \mathrm{N}_{2}+\mathrm{O}$.

This mechanism is the primary method whereby odd nitrogen $\left(\mathrm{NO}_{\mathrm{y}}\right)$ is returned to even nitrogen $\left(\mathrm{N}_{2}\right)$.

\subsection{Model Computations- Yearly Production of $\mathrm{NO}_{y}$}

There are other sources of $\mathrm{NO}_{\mathrm{y}}$ in the atmosphere and the importance of SPEs in producing $\mathrm{NO}_{\mathrm{y}}$ becomes clear only when comparing to these other sources. A summary of the computations of the production of $\mathrm{NO}_{\mathrm{y}}$ molecules per year is given in Figure 6 for the northern polar stratosphere (lati- tudes $>50^{\circ} \mathrm{N}$ ) over the 1955 to 1993 time period [Jackman et al., 2000]. The sources include SPEs, GCRs, "in situ" oxidation of $\mathrm{N}_{2} \mathrm{O}$, and horizontal transport from lower latitudes.

The full histograms indicate the SPE-caused $\mathrm{NO}_{y}$ production for both the stratosphere and mesosphere, while the light gray areas of the histograms indicate the SPE-caused stratospheric $\mathrm{NO}_{\mathrm{y}}$ production only. The annual production rates of $\mathrm{NO}_{\mathrm{y}}$ from GCRs, "in situ" oxidation of $\mathrm{N}_{2} \mathrm{O}$, and horizontal transport from lower latitudes are represented in Figure 6 by the solid, dash-dot and dashed lines, respectively. There is only about a $10 \%$ variation in the "in situ" oxidation of $\mathrm{N}_{2} \mathrm{O}$ and horizontal transport from lower latitudes, caused by the solar cycle ultraviolet flux variation which feeds into each of these sources [Vitt and Jackman, 1996]. This minor variation is hardly noticeable on the log scale used for the ordinate in the figure and the constant values of $1 \times 10^{33}$ and $9 \times 10^{33} \mathrm{NO}_{\mathrm{y}}$ molecules/year are assumed for the "in situ" oxidation of $\mathrm{N}_{2} \mathrm{O}$ and horizontal transport of $\mathrm{NO}_{y}$ from lower latitudes, respectively. The GCR contribution to $\mathrm{NO}_{\mathrm{y}}$ was computed to vary from 6.9 to $9.6 \times 10^{32}$ molecules/year.

There is another source of $\mathrm{NO}_{\mathrm{y}}$ in the polar middle atmosphere, energetic electrons. Unfortunately, we do not have a very reliable estimate of this source of $\mathrm{NO}_{y}$ on an annual

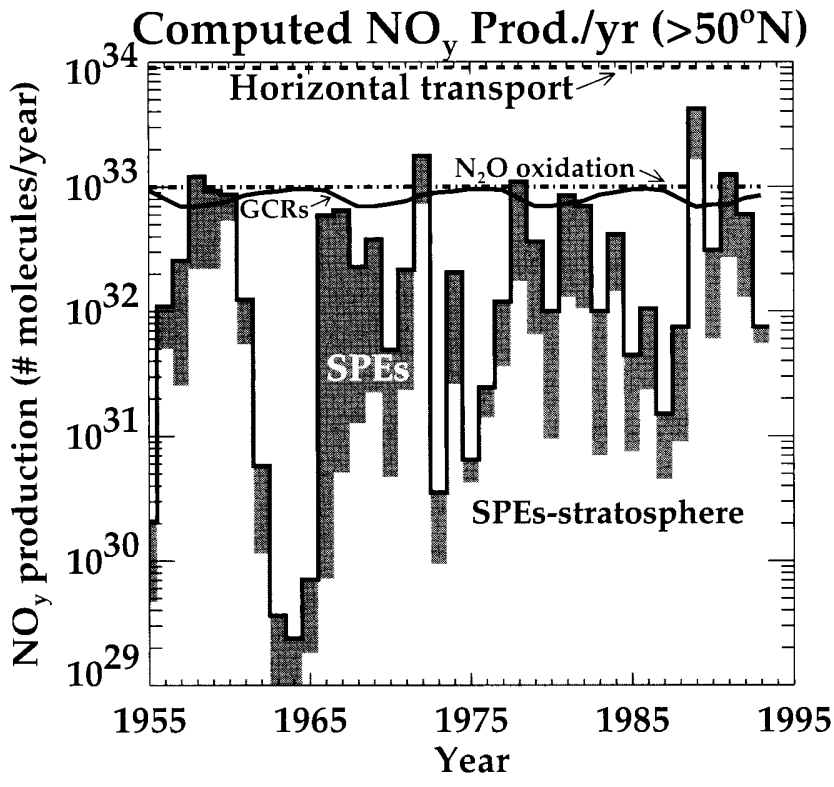

Figure 6. Taken from Fig. 1 of Jackman et al. [2000]. Total number of $\mathrm{NO}_{\mathrm{y}}$ molecules produced per year in the northern polar stratosphere by SPEs (histogram indicating both the total and the stratospheric contributions), galactic cosmic rays (GCRs) indicated by solid line, $\mathrm{N}_{2} \mathrm{O}$ oxidation in the polar region only (dash-dot line), and horizontal transport of $\mathrm{NO}_{\mathrm{y}}$ from lower latitudes into this region (dashed line). 
basis. The higher energy electrons and associated bremsstrahlung provide a direct middle atmospheric source of $\mathrm{NO}_{\mathrm{y}}$ and the lower energy electrons provide an indirect source that is dependent on the downward transport of the $\mathrm{NO}_{\mathrm{y}}$ to the middle atmosphere during polar night.

The oxidation of $\mathrm{N}_{2} \mathrm{O}$ at lower latitudes and subsequent horizontal transport of $\mathrm{NO}_{y}$ into the polar regions is about an order of magnitude larger than the $\mathrm{NO}_{\mathrm{y}}$ sources of GCRs and "in situ" oxidation of $\mathrm{N}_{2} \mathrm{O}$. The $\mathrm{NO}_{\mathrm{y}}$ production from SPEs for the periods 1955-1973 and 1974-1993 was taken from Jackman et al. [1980] and Vitt and Jackman [1996], respectively. This SPE-generated annual production of $\mathrm{NO}_{y}$ is computed to vary by orders of magnitude over the 1955 1993 time period. There is a general solar cycle dependence with more (less) SPE-produced $\mathrm{NO}_{\mathrm{y}}$ near solar maximum (minimum). The annual SPE source of $\mathrm{NO}_{y}$ in the Northern Hemisphere was larger than $1.2 \times 10^{33} \mathrm{NO}_{\mathrm{y}}$ molecules/year during only 2 years (1972 and 1989). These were years in which very large fluxes of extremely energetic protons accompanied the SPEs in August 1972 and October 1989.

\subsection{Measurements and Model Computations of July 2000 $\mathrm{SPE}$-produced $\mathrm{NO}_{\mathrm{y}}$}

The recent SPE of July 2000 also produced substantial changes in $\mathrm{NO}_{\mathrm{y}}$. Measurements of HALOE NO and $\mathrm{NO}_{2}$ during [Jackman et al., 2001] and a couple of months after the event [Randall et al., 2001] indicated very large increases as a result of this event. Figure 7 a shows the increases in HALOE Version $19 \mathrm{NO}_{\mathrm{x}}\left(\mathrm{NO}+\mathrm{NO}_{2}\right)$ above background. The HALOE measurements were taken at different longitudes and slightly different latitudes $\left(65.4^{\circ} \mathrm{N}\right.$ to $\left.68.5^{\circ} \mathrm{N}\right)$ over the July 12-15 period, however, the $\mathrm{NO}_{\mathrm{x}}$ changes resulting from the July 2000 SPE dominated any of the geographically-caused differences. The apparent enhancements in HALOE $\mathrm{NO}_{\mathrm{x}}$ above $0.03 \mathrm{hPa}$ during the first half of July 14 are probably related to other natural variabilities and not due to the SPE. Enhancements of $\mathrm{NO}_{\mathrm{x}}$ greater than $50 \mathrm{ppbv}$ and 200 ppbv are observed at $0.3 \mathrm{hPa}$ and $0.01 \mathrm{hPa}$, respectively, near the end of July 15. Background $\mathrm{NO}_{\mathrm{x}}$ levels are typically $1-5 \mathrm{ppbv}$ at $0.3 \mathrm{hPa}$ and $20-60 \mathrm{ppbv}$ at $0.01 \mathrm{hPa}$, thus the $\mathrm{NO}_{\mathrm{x}}$ increases caused by this SPE were very large.

Model computed $\mathrm{NO}_{\mathrm{x}}$ changes for $65^{\circ} \mathrm{N}$ are given in Figure $7 \mathrm{~b}$. The predicted increase in the $\mathrm{NO}_{\mathrm{x}}$ constituents from the SPE are similar to the measurements in the stratosphere and lower mesosphere up to $\sim 0.3 \mathrm{hPa}$. However, in the middle and upper mesosphere $(<0.3 \mathrm{hPa})$, the model predicts larger increases in the $\mathrm{NO}_{\mathrm{x}}$ than observed. It is possible that some of these model/measurement differences may be related to the fraction of atomic $\mathrm{N}$ produced by the protons and associated electrons that end up in excited states (e.g., $\left.\mathrm{N}\left({ }^{2} \mathrm{D}\right)\right)$ or the ground state $\left(\mathrm{N}\left({ }^{4} \mathrm{~S}\right)\right)$. The family modeling approach of Jackman et al. [2001] assumed that virtually all the $\mathrm{NO}_{y}$ produced above $0.3 \mathrm{hPa}$ by the July 2000 SPE was in the form of NO, implying a nearly $100 \%$ production of $\mathrm{N}\left({ }^{2} \mathrm{D}\right)$ by the precipitating particles. Rusch et al. [1981] showed that there are huge differences in the final results of model computations of $\mathrm{NO}_{\mathrm{y}}$ enhancements from SPEs that depend strongly on the branching ratios of the $\mathrm{N}$ atoms produced. Further study of these model/measurement

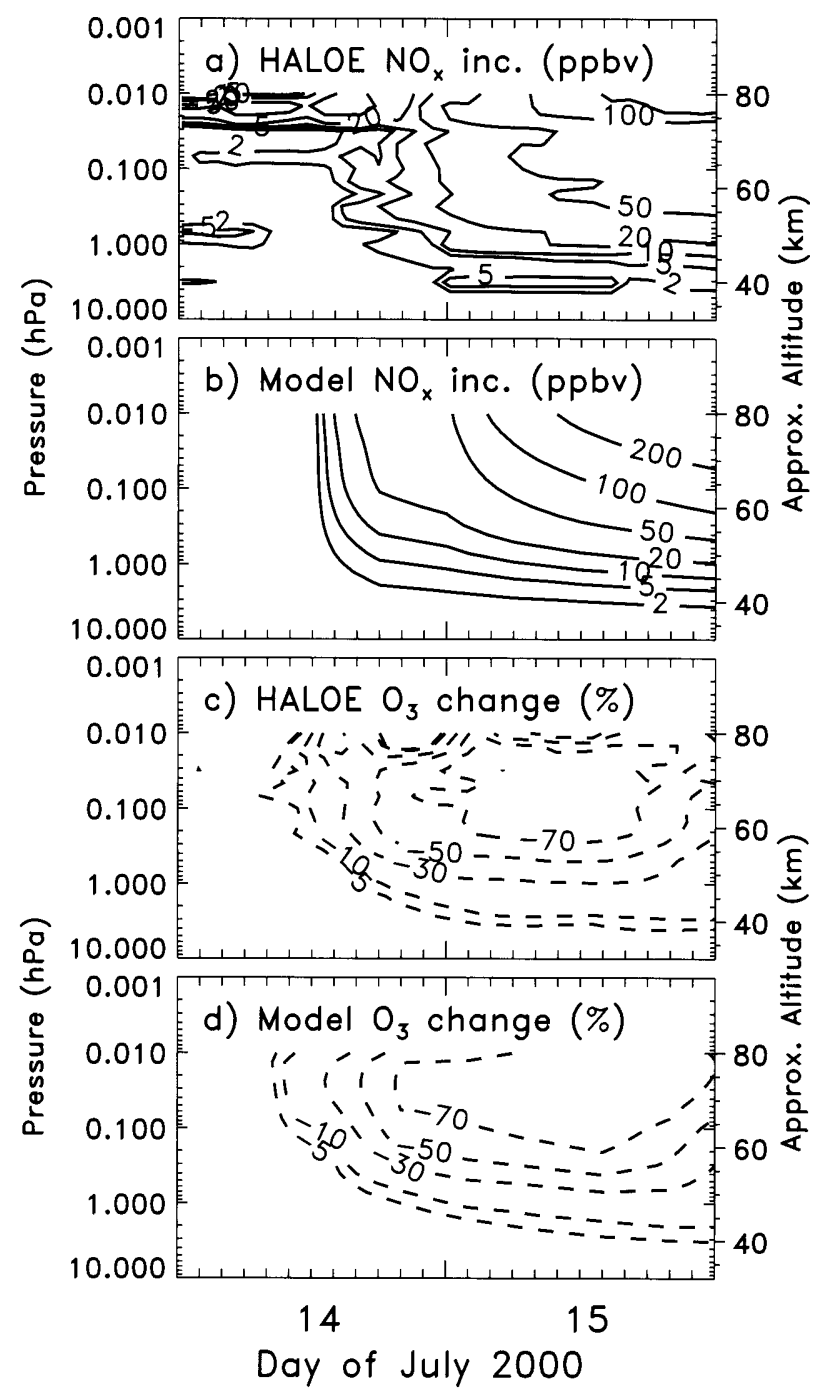

Figure 7. Taken from Fig. 2 of Jackman et al. [2001]. Polar Northern Hemisphere pressure versus time cross sections during the SPE period (July 14-15, 2000) for a) HALOE $\mathrm{NO}_{\mathrm{x}}$ and b) model $\mathrm{NO}_{\mathrm{x}}$ increases, both for contour levels 2, 5, 10, 20, 50, 100, and $200 \mathrm{ppbv}$; and c) HALOE ozone and d) model ozone decreases, both for contour levels $-5,-10,-30,-50$, and $-70 \%$. The HALOE $\mathrm{NO}_{\mathrm{x}}$ and ozone changes were computed by comparing to the background average of the July 12-13 observations. 
differences is needed to sort out the discrepancies.

Randall et al. [2001] showed evidence that the large $\mathrm{NO}_{\mathrm{x}}$ enhancements from the July 2000 SPE lasted for at least two months past the event. They showed HALOE measurements in early September 2000 in the Southern Hemisphere polar vortex, indicating substantial enhancements of $\mathrm{NO}_{\mathrm{x}}$ in the middle stratosphere. These large increases were almost certainly caused by the July 2000 SPE. The $\mathrm{NO}_{\mathrm{x}}$ peak in the southern polar middle stratosphere occurred near $32 \mathrm{~km}$ and was probably a result of descent of the SPE-created $\mathrm{NO}_{\mathrm{x}}$ from the mesosphere and upper stratosphere during the winter [Randall et al., 2001].

\section{OZONE EFFECTS BY SPES}

Ozone is influenced by SPEs through the production of both $\mathrm{HO}_{\mathrm{x}}$ and $\mathrm{NO}_{\mathrm{y}}$ constituents. There are measured influences on atmospheric constituents during eleven large SPEs (Table 1). These SPEs all showed ozone decreases and three of the SPEs had $\mathrm{NO}$ or $\mathrm{NO}_{2}$ increases that were measured as well as discussed in the previous section. A number of papers over a span of nearly 30 years have provided the evidence of these SPE influences on ozone in the atmosphere.

Solar cycle 20 provided the first evidence of atmospheric effects by SPEs. Weeks et al. [1972] described large mesospheric ozone decreases associated with the November 1969 SPE in this solar cycle. The ozone decreases caused by the August 1972 SPEs, the second largest episode of SPEs in the past 30 years, were originally shown in the Nimbus 4 satellite BUV instrument data in Heath et al. [1977] and were reanalyzed by McPeters et al. [1981], who was able to subtract the direct effects of the high energy protons on the BUV instrument. Reagan et al. [1981] showed the spatial extent of the ozone depletion and Jackman and McPeters [1987] were able to provide ozone depletion information for nearly two months after the August 1972 SPEs, again using BUV data. McPeters et al. [1981] was also able to provide reliable information about substantial short-lived ozone depletion at $1 \mathrm{mbar}(\sim 50 \mathrm{~km})$ and above as a result of the January and September 1971 SPEs using BUV data.

Both the Solar Mesosphere Explorer (SME) satellite [Thomas et al., 1983] and the SBUV instrument aboard Nimbus 7 [McPeters and Jackman, 1985] showed large mesospheric depletions during the large July 1982 SPE. McPeters and Jackman [1985] studied other SPEs in solar cycle 21 and provided evidence of ozone depletion in June and August 1979, October 1981, and December 1982.

The largest SPEs of the past 30 years occurred in solar cycle 22 in October 1989. Measurements by NOAA-11 SBUV/2 [Jackman et al., 1993] and SAGE II [Jackman et al., 1995] indicated very substantial long-term ozone depletion caused by this event.

A more recent SPE in July 2000 during solar cycle 23 caused ozone depletion that was measured by the NOAA-14 SBUV/2 and UARS HALOE instruments [Jackman et al., 2001]. This SPE was the third largest in the past 30 years and provided good information about the spatial and temporal extent of the ozone changes caused by this atmospheric disturbance. Other large SPEs in this solar cycle that probably caused ozone decreases occurred in November 2000 and November 2001.

All SPEs produce both $\mathrm{HO}_{\mathrm{x}}$ and $\mathrm{NO}_{\mathrm{y}}$ constituents, both of which influence ozone. Some of these SPE-related ozone influences are short-term, caused by the $\mathrm{HO}_{\mathrm{x}}$ increases, whereas others are longer-term, caused by the $\mathrm{NO}_{\mathrm{y}}$ increases. These different ozone effects will be discussed below.

\subsection{Short-term Effects from $\mathrm{HO}_{x}$ Constituents}

The depletion of ozone by the SPE-enhanced $\mathrm{HO}_{\mathrm{x}}$ constituents has been simulated in several papers [e.g., Swider and Keneshea, 1973; Frederick, 1976; Swider et al., 1978; Solomon et al., 1981; Jackman and McPeters, 1985]. All the SPEs given in Table 1 have a $\mathrm{HO}_{\mathrm{x}}$-induced ozone depletion associated with them. As noted in section 3, the $\mathrm{HO}_{\mathrm{x}}$ constituents do not last more than a couple of hours after an $\mathrm{SPE}$. However, the $\mathrm{HO}_{\mathrm{x}}$ constituents can have very significant influences on ozone, especially in the mesosphere. There are several catalytic processes through which the $\mathrm{HO}_{\mathrm{x}}$ constituents destroy ozone.

An important catalytic process in the stratosphere $(\sim 10$ $50 \mathrm{~km}$ ) which leads to ozone destruction is:

$$
\begin{aligned}
& \mathrm{OH}+\mathrm{O}_{3} \rightarrow \mathrm{HO}_{2}+\mathrm{O}_{2} \\
& \mathrm{O}+\mathrm{HO}_{2} \rightarrow \mathrm{OH}+\mathrm{O}_{2} \\
& \text { Net: } \mathrm{O}_{3}+\mathrm{O} \rightarrow 2 \mathrm{O}_{2} .
\end{aligned}
$$

At mesospheric altitudes $(\sim 50-90 \mathrm{~km})$ the catalytic process

$$
\begin{aligned}
& \mathrm{H}+\mathrm{O}_{3} \rightarrow \mathrm{OH}+\mathrm{O}_{2} \\
& \mathrm{O}+\mathrm{OH} \rightarrow \mathrm{H}+\mathrm{O}_{2} \\
& \text { Net: } \mathrm{O}+\mathrm{O}_{3} \rightarrow 2 \mathrm{O}_{2}
\end{aligned}
$$

is a dominant mechanism for ozone destruction.

The influence of a SPE on ozone through the $\mathrm{HO}_{\mathrm{x}}$ constituents is very dependent on the solar zenith angle. The ambient $\mathrm{HO}_{\mathrm{x}}$ level is maintained by the following two mechanisms

$$
\mathrm{H}_{2} \mathrm{O}+\mathrm{h} v \rightarrow \mathrm{H}+\mathrm{OH} \text { (dominant above } 70 \mathrm{~km} \text { ) }
$$


and $\mathrm{O}\left({ }^{1} \mathrm{D}\right)+\mathrm{H}_{2} \mathrm{O} \rightarrow \mathrm{OH}+\mathrm{OH}$ (dominant below $70 \mathrm{~km}$ )

Both of these reactions are only active in the sunlight. The first mechanism is directly dependent on the sun and the second mechanism is dependent on the production of $\mathrm{O}\left({ }^{1} \mathrm{D}\right)$, a very short-lived constituent, which is produced by the photolysis of $\mathrm{O}_{3}$. Since the $\mathrm{HO}_{x}$ production by the SPEs is not dependent on sunlight (see section 3), the SPE-produced $\mathrm{HO}_{\mathrm{x}}$ will have a larger impact on ozone at larger solar zenith angles, where the ambient $\mathrm{HO}_{\mathrm{x}}$ production is less. Solomon et al. [1983] and Jackman and McPeters [1985] provide further details about this solar zenith angle dependence of the SPE-produced $\mathrm{HO}_{\mathrm{x}}$ impact on ozone.

This dependence of the ozone depletion caused by SPEproduced $\mathrm{HO}_{\mathrm{x}}$ on solar zenith angle can be seen quite well in Figure 8 taken from Solomon et al. [1983]. The figure shows both model computations and measurements during different portions of the Solar Mesosphere Explorer (SME) orbit. The model computations are close to the observations during the AM portions of the SME orbit, the AM portion of the orbit being at the very large solar zenith angles. There is less agreement between the model and observations during the PM portions of the SME orbit. Notice that the measurements show larger amounts of ozone depletion at the larger solar zenith angles, consistent with theoretical predictions.

The ozone depletion during the July 2000 SPE was also mostly caused by the $\mathrm{HO}_{\mathrm{x}}$ production (shown in Figure 7). The percentage decreases in the HALOE sunrise ozone measurements are given in Figure 7c where the July 1415 values are compared to the background average of the July 12-13 observations. The HALOE observed ozone reductions started on July 14 and reached over $70 \%$ during most of July 15 in the middle mesosphere between 0.3 and $0.01 \mathrm{hPa}$. The model computations in Figure $7 \mathrm{~d}$ are fairly similar to the HALOE measurements during most of the event.

Although there appears to be reasonable agreement between the model and HALOE measurements, Jackman et al. [2001] did point out some discrepancies between the model and SBUV/2 measurements at $1-2 \mathrm{hPa}(\sim 45-50 \mathrm{~km})$. The SBUV/2 measurements indicated a larger ozone depletion than predicted. Reaction rate adjustments for $\mathrm{HO}_{\mathrm{x}}$ constituents discussed in Conway et al. [2000] did not help the model/measurement agreement. These discrepancies need to be investigated further.

\subsection{Long-term Effects from $\mathrm{NO}_{y}$ Constituents}

The influence of the SPE-enhanced $\mathrm{NO}_{\mathrm{y}}$ constituents on ozone has been understood nearly as long as the impact of the SPE-enhanced $\mathrm{HO}_{\mathrm{x}}$ constituents. Crutzen et al. [1975] predicted that the nitric oxide (NO) produced during three large SPEs between 1960 and 1972 would probably have been enough to cause an ozone change. The Heath et al. [1977] results showed that there were large stratospheric ozone reductions apparent in the Nimbus- 4 BUV instrument data up to 19 days past the August 1972 events and were probably caused by the $\mathrm{NO}_{\mathrm{y}}$ enhancements. Several other papers, including Fabian et al. [1979], Maeda and Heath [1980/1981], Reagan et al. [1981], Solomon and Crutzen [1981], Rusch et al. [1981], and Jackman et al. [1990, 1995, $2000]$, studied various aspects of $\mathrm{NO}_{\mathrm{y}}$ influence on stratos-
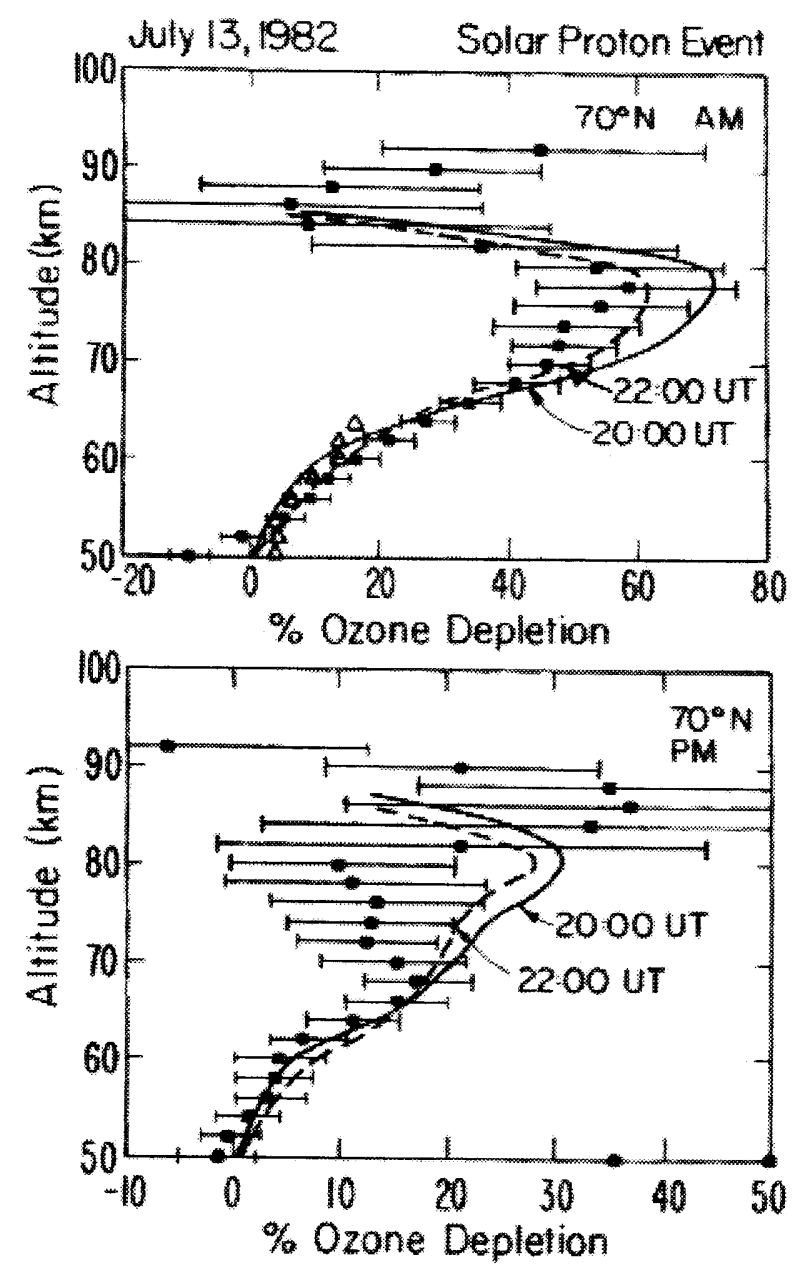

Figure 8. Taken from Fig. 3 of Solomon et al. [1983]. Observed ozone depletion on July 13,1982 at $70^{\circ} \mathrm{N}$ latitude on the AM and PM portions of the Solar Mesosphere Explorer (SME) orbit (each point represents a mean of three orbits on July 13, 1982 near 1830 , 2120 , and 2206 UT). Triangles denote data from the UV spectrometer. Model calculated profiles for 2000 and 2200 UT are shown. 
pheric ozone. The primary catalytic cycle for $\mathrm{NO}_{\mathrm{y}}$ destruction of ozone is

$$
\begin{aligned}
& \mathrm{NO}+\mathrm{O}_{3} \rightarrow \mathrm{NO}_{2}+\mathrm{O}_{2} \\
& \mathrm{NO}_{2}+\mathrm{O} \rightarrow \mathrm{NO}+\mathrm{O}_{2} \\
& \text { Net: } \mathrm{O}_{3}+\mathrm{O} \rightarrow 2 \mathrm{O}_{2}
\end{aligned}
$$

A comparison of the Nimbus 4 BUV measurements and model predictions of ozone destruction caused by the extremely large August 1972 SPEs is given in Figure 9. Virtually all the ozone destruction observed beyond day 222 was caused by the $\mathrm{NO}_{y}$ enhancements from this SPE. Both the measurements and model computations indicate ozone depletions of over $20 \%$ in the upper stratosphere during the SPE with depletions of over $15 \%$ persisting for about two months after the SPE. The major difference between the measurements and model results is in the upper stratospheric and lower mesospheric region (near $50 \mathrm{~km}$ ), where the model indicates a faster recovery from the initial SPE-caused ozone depletion than is indicated in the measurements.

The long lifetime of the $\mathrm{NO}_{\mathrm{y}}$ constituents allows the influence on ozone to last for a number of months past the event. Figure 10 shows the model predicted temporal behavior of profile ozone and $\mathrm{NO}_{\mathrm{y}}$ for $1989-1992$ at $75^{\circ} \mathrm{N}$. Predicted upper stratospheric increases in $\mathrm{NO}_{\mathrm{y}}$ over $100 \%$ during and shortly after the extremely large October 1989 SPEs produced significant upper stratospheric ozone decreases $(>10 \%)$. The downward transport in the late fall and winter caused the very large enhancements of $\mathrm{NO}_{\mathrm{y}}$ in the upper stratosphere to be moved to lower stratospheric levels with a corresponding ozone decrease. $\mathrm{NO}_{\mathrm{y}}$ enhancements of over $10 \%$ accompanied by ozone decreases of greater than $2 \%$ persisted for over a year past these events. Ozone decreases down to 100 mbar $(\sim 16 \mathrm{~km})$ were predicted by the spring of 1990 as a result of these events in 1989 .

Although most recent theoretical studies have been completed with two-dimensional (2D) atmospheric models, three-dimensional (3D) atmospheric models have also played a role in our understanding of the influence of SPEs on the atmosphere. Jackman et al. [1993] was able to simulate the large Northern and Southern Hemisphere measured differences in ozone response from the October 1989 SPEs with a 3D model over the October-December 1989 time period, whereas they were unable to simulate these interhemispheric differences with a 2D model. Jackman et al. [1995] used a 3D model to simulate the time period October 1989 to April 1990 to study the longer term influences of the October 1989 SPEs. They found a reasonable simulation of the SAGE II NO 2 observations. The Jackman et al. [1995] simulations found less good agreement with SAGE II ozone changes and suggested that other factors, such as heteroge- (a) BUV $\mathrm{O}_{3} \%$ CHANGE $\left(70-80^{\circ} \mathrm{N}\right)-1972$

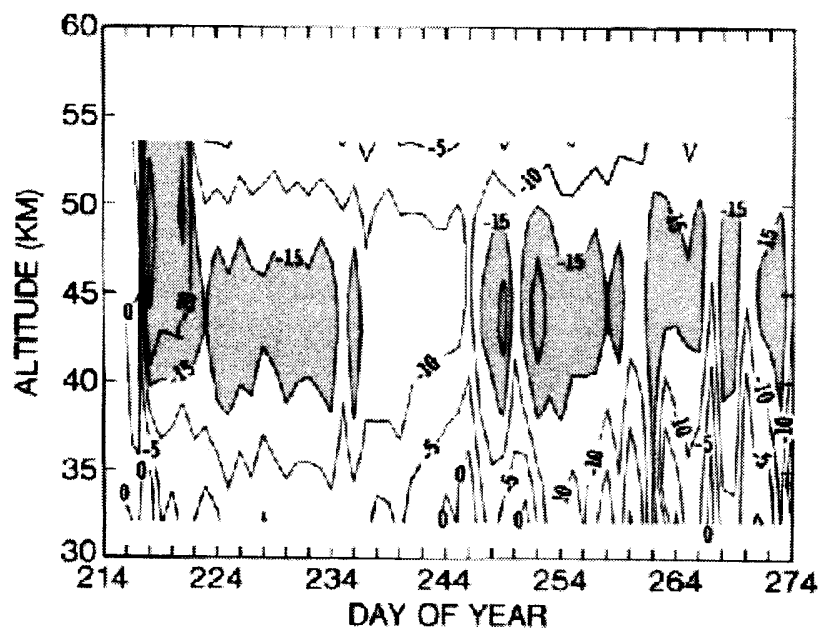

(b) MOOEL $0_{3}$ \% CHANGE AT $75 \mathrm{~N}-1972$

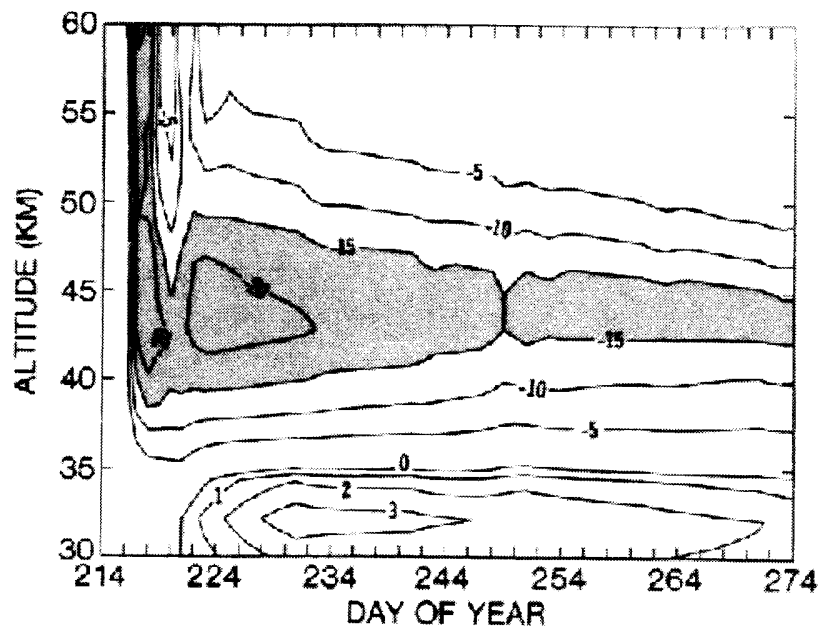

Figure 9. Taken from Figs. 6a and 7a of Jackman et al. [1990]. (a) Nimbus 4 BUV measured ozone percentage change as a function of day of year in 1972 for $70^{\circ}-80^{\circ} \mathrm{N}$ band. (b) Model predicted ozone percentage change as a function of day of year in 1972 for $75^{\circ} \mathrm{N}$. The contour levels of $-30,-20,-15,-10,-5,0,+1,+2$, and $+3 \%$.

neous chemistry, might also be influencing constituents of this region.

\subsection{Self-healing and Halogen Interference Leading to Ozone Increases}

Ozone is usually depleted by SPE enhancements of $\mathrm{HO}_{\mathrm{x}}$ and $\mathrm{NO}_{\mathrm{y}}$, but it can also be increased in certain regions. Jackman and McPeters [1985] showed that ozone "selfhealing" should also be associated with SPEs. When ozone is decreased at a higher altitude, increased ultraviolet (UV) 

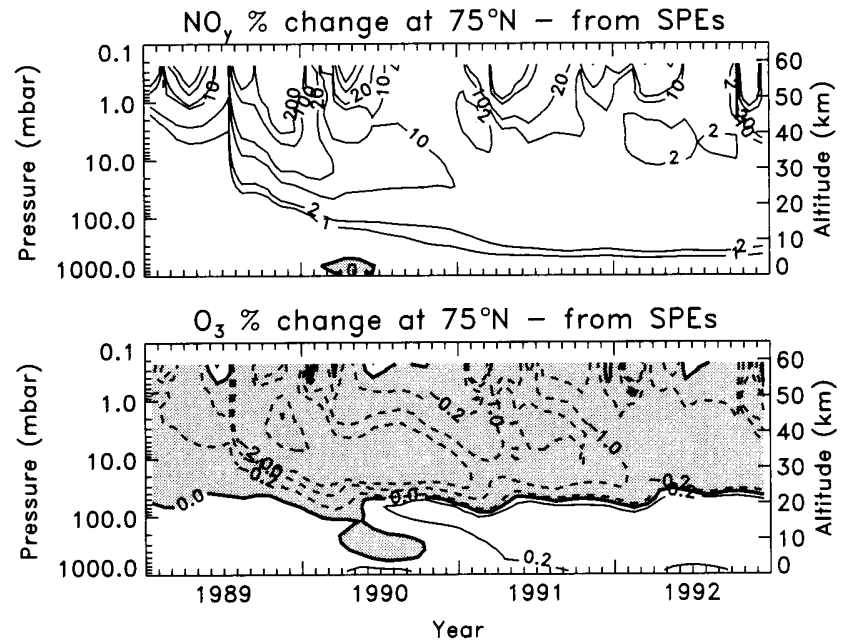

Figure 10. Taken from Fig. 6 of Jackman et al. [2000]. Modelcomputed percentage changes in $\mathrm{NO}_{\mathrm{y}}$ and $\mathrm{O}_{3}$ at $75^{\circ} \mathrm{N}$ for 1989 1992 resulting from SPEs. Contour intervals for $\mathrm{NO}_{\mathrm{y}}$ are $0,1,2$, $10,20,100$, and $200 \%$. Contour intervals for $\mathrm{O}_{3}$ are $+0.2,0,-0.2$, $-1,-2,-10$, and $-20 \%$.

radiation penetrates to lower altitudes. The increased UV radiation at very low altitudes (or extremely large solar zenith angles) can lead to an ozone production due to an increase in $\mathrm{O}_{2}$ dissociation

$$
\mathrm{O}_{2}+\mathrm{h} v(<242 \mathrm{~nm}) \rightarrow \mathrm{O}+\mathrm{O}
$$

followed by

$$
\begin{aligned}
& \mathrm{O}+\mathrm{O}_{2}+\mathrm{M} \rightarrow \mathrm{O}_{3} \\
& \text { and } \mathrm{O}+\mathrm{O}_{2}+\mathrm{M} \rightarrow \mathrm{O}_{3} .
\end{aligned}
$$

Predicted ozone increases below about 40 mbar $(\sim 22 \mathrm{~km})$ in 1989 in Figure 10 (lower graph) are the result of selfhealing. Such effects are small and the ozone self-healing only partially compensates for the higher altitude depletion of ozone caused by the SPE-enhanced $\mathrm{NO}_{y}$.

The ozone enhancements in the lowest part of the stratosphere (below $\sim 22 \mathrm{~km}$ ) in late 1990, 1991, and 1992 shown in Figure 10 (lower graph) were caused by the interference of downward transported $\mathrm{NO}_{\mathrm{y}}$ with chlorine and bromine constituents [Jackman et al., 2000]. More $\mathrm{ClO}$ and $\mathrm{BrO}$ radicals were tied up into the reservoir species $\mathrm{ClONO}_{2}$ and $\mathrm{BrONO}_{2}$ by the enhanced $\mathrm{NO}_{2}$ in the lower stratosphere through

$$
\begin{aligned}
& \mathrm{ClO}+\mathrm{NO}_{2}+\mathrm{M} \rightarrow \mathrm{ClONO}_{2}+\mathrm{M} \\
& \text { and } \mathrm{BrO}+\mathrm{NO}_{2}+\mathrm{M} \rightarrow \mathrm{BrONO}_{2}+\mathrm{M}
\end{aligned}
$$

Since the chlorine and bromine radicals are very important in the control of ozone in the lower stratosphere, the interference production of the reservoir species $\mathrm{ClONO}_{2}$ and $\mathrm{BrONO}_{2}$ resulted in a net decrease in the catalytic loss of ozone. This process then led to a predicted ozone increase, which is especially important in periods of high chlorine and bromine loading such as the present time [Jackman et al., 2000].

\subsection{Total Column Ozone Changes}

The predicted influence of the SPEs in October 1989 on total column ozone is illustrated in Figure 11. This largest period of SPEs of the past 30 years was predicted to have caused a maximum total ozone depletion of about $2 \%$. The largest predicted ozone depletions due to these SPEs were in late 1989 and 1990. Total ozone depletions were less in 1991 and were almost non-existent or positive in 1992. These impacts on total column ozone are fairly small and would be difficult to discern in measurements because of large daily fluctuations at polar latitudes due to meteorological and seasonal variations [e.g., see WMO, 1999]. Marin and Lastovicka [1998] were not able to find any signal for SPEs in a Dobson total ozone record for central Europe $\left(50^{\circ} \mathrm{N}\right)$.

The influence of SPEs on global total ozone variations was compared to the other natural (solar cycle ultraviolet variations and large volcanic eruptions) fluctuations as well as the anthropogenically-caused ozone variations in Jackman et al. [1996]. The annually averaged almost global total ozone, computed between $65^{\circ} \mathrm{S}$ and $65^{\circ} \mathrm{N}$, was predicted in Jackman et al. [1996] to: 1) decrease $4 \%$ from 1979 to 1995 due to anthropogenically-induced increases of chlorine and bromine; 2 ) decrease a maximum of $\sim 2.8 \%$ in 1992 as a result of the very large Mt. Pinatubo volcanic

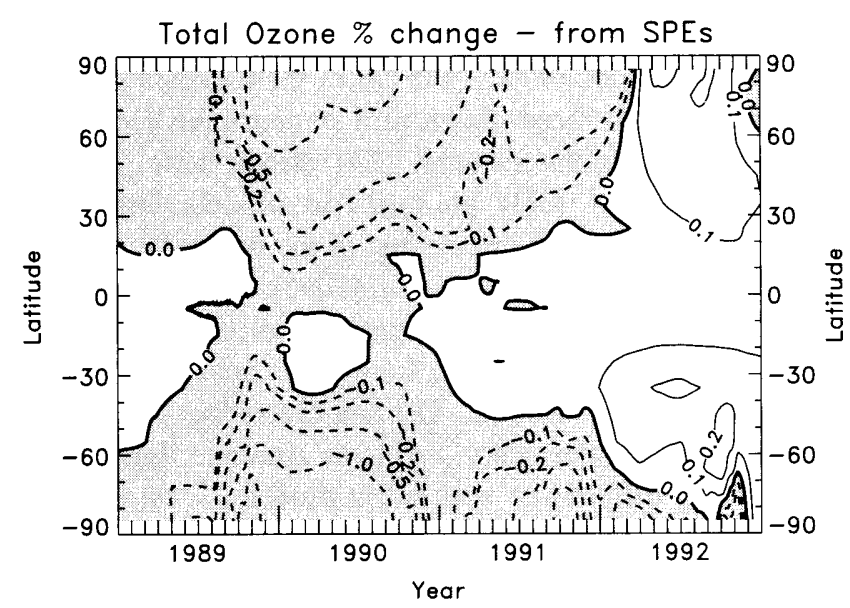

Figure 11. Taken from Fig. 3 of Jackman et al. [2000]. Modelcomputed percentage total ozone changes from 1989-1992 resulting from SPEs. Contour intervals are $+0.2,+0.1,0,-0.1,-0.2$, $-0.5,-1$, and $-2 \%$. 
eruption; 3) vary by $\sim 1.2 \%$ as a result of solar ultraviolet flux variations over a solar cycle; 4 ) decrease by $\sim 0.2 \%$ as a result of the extremely large SPEs in October 1989; and 5) vary by $\sim 0.02 \%$ as a result of GCRs over a solar cycle. The influence of SPEs on global total ozone variations is thus rather small compared to other natural and humankindcaused fluctuations or trends.

\section{SPE-CAUSED TEMPERATURE AND DYNAMICAL VARIATIONS}

Large SPEs can also influence temperature and dynamics in the middle atmosphere. The temperature change associated with SPEs has been discussed in previous studies [e.g., Banks, 1979; Reagan et al., 1981; Jackman and McPeters, 1985; Roble et al., 1987; Reid et al., 1991; and Jackman et al., 1995]. Other studies [Rottger, 1992; Johnson and Luhmann, 1993] have documented changes in long-period gravity waves and neutral winds in the polar mesosphere as a result of SPEs.

SPEs can cause both heating and cooling of the middle atmosphere. Direct atmospheric heating is caused by the precipitating particles through Joule heating. Banks [1979] computed Joule dissipation temperature rate changes of $1^{\circ}$ to $10^{\circ} \mathrm{K}$ per day in the mesosphere as a result of the very large August 1972 SPEs. Roble et al. [1987] computed similar mesospheric temperature rate changes during the July 1982 SPE. The July 1982 SPE was comparable to the August 1972 SPEs in the mesosphere. These mesospheric temperature rate forcings from Joule heating are comparable to or larger than the solar ultraviolet heating in this region and could cause small short-term temperature increases. Negligible temperature rate changes via Joule heating were computed in the stratosphere as a result of these SPEs.

Since ozone is one of the primary radiative absorbing (heating) gases of the middle atmosphere, a decrease in ozone as a result of SPEs could be expected to result in lower temperatures. Reagan et al. [1981] calculated a temperature decrease of $2.2^{\circ} \mathrm{K}$ at $50 \mathrm{~km}$ during the extremely large August 1972 SPEs. Jackman and McPeters [1985] computed a temperature decrease of a maximum of $1.1^{\circ} \mathrm{K}$ at $50 \mathrm{~km}$ due to the July 1982 SPE. The July 1982 SPE was smaller than the August 1972 SPEs in the stratosphere. Reid et al. [1991] and Jackman et al. [1995] calculated maximum temperature decreases of about $3^{\circ} \mathrm{K}$ at $75^{\circ} \mathrm{S}$ in the upper stratosphere $(40-50 \mathrm{~km})$ as a result of the very large October 1989 SPEs. These temperature changes are longer-lived than those associated with the Joule heating and would last as long as the SPE-caused ozone decreases, which could be for several months in the stratosphere.
Rottger [1992] discussed large wave amplitudes in the meridional wind (long-period gravity waves) in the polar lower mesosphere during SPEs in October and December of 1989. These changes may be caused by the Joule heating as well as the heating rate changes generated from ozone depletions, both effects from SPEs. Such SPE-caused atmospheric variations follow a certain temporal and spatial variation and could produce vertical wavelengths of about $10 \mathrm{~km}$ and northward velocities up to $\pm 40 \mathrm{~m} \mathrm{~s}^{-1}$ due to the wave [Rottger, 1992].

Consistent with these observations by Rottger [1992], Johnson and Luhmann [1993] showed observations of variations in upper mesospheric neutral winds accompanying the July 1982 and April 1984 SPEs. As a result of the July 1982 SPE, the mean wind shifted to the west-southwest by 5-30 $\mathrm{m} \mathrm{s}^{-1}$ over the $81-90 \mathrm{~km}$ range, which was approximately twice the normal standard deviation. Similar mean wind shifts were observed as a result of the April 1984 SPE, although this occurred primarily at lower altitudes (65-75 $\mathrm{km})$. Johnson and Luhmann [1993] speculate that the Joule heating and ozone depletion probably played a role in the SPE-related wind changes.

\section{CONCLUSIONS}

The polar middle atmosphere is readily influenced by large SPEs. SPEs can cause huge changes in the constituents in the polar middle atmosphere and can be used to study the natural variations in ozone. $\mathrm{HO}_{\mathrm{x}}$ increases of greater than $100 \%$ at high solar zenith angles were computed in the mesosphere as a result of large SPEs. The $\mathrm{NO}_{\mathrm{y}}{ }^{-}$ induced stratospheric increases from SPEs are more persistent and are computed to be greater than $10 \%$ for over a year past the extremely large October 1989 SPEs.

The ozone depletion in eleven SPEs was documented in the refereed literature in the last 32 years. All these SPEs showed ozone depletions during the events, which were primarily $\mathrm{HO}_{\mathrm{x}}$-induced. The $\mathrm{HO}_{\mathrm{x}}$-induced ozone depletions from the larger SPEs were computed and measured at high solar zenith angles to be quite large $(>50 \%)$ in the middle to upper mesosphere. Three of these SPEs had lingering ozone depletions past the events, which were primarily $\mathrm{NO}_{\mathrm{y}}-$ induced. Ozone depletions of $15 \%$ from the extremely large August 1972 SPEs persisted for two months after these events in the upper stratosphere.

Polar total column ozone was computed to be decreased by a maximum of about $2 \%$ as a result of the extremely large October 1989 SPEs. Annually averaged global total ozone decreases were calculated to be $0.2 \%$ in 1990 as a result of these events, relatively small compared to other natural and humankind related changes. 
SPEs may also change the temperature and dynamics of the middle atmosphere either directly through Joule heating or indirectly through an associated ozone depletion. Joule heating from very large SPEs was comparable to or larger in the mesosphere to the solar ultraviolet heating. Polar mesospheric temperatures were predicted to be lowered through ozone depletion in the upper stratosphere by $1-3^{\circ} \mathrm{K}$ as a result of very large SPEs Gravity waves and winds in the mesosphere were observed to vary as a result of these changed heating rates from the SPEs.

These solar events input quantifiable amounts of $\mathrm{HO}_{\mathrm{x}}$ and $\mathrm{NO}_{\mathrm{y}}$ into the atmosphere and can be used to test the current understanding of the atmospheric chemistry and dynamics. Although there is a general agreement between model predictions and measurements concerning SPE-induced ozone influences, some differences remain. The largest differences between the measured and modeled ozone depletions caused by SPEs occur in the upper stratosphere, both for the $\mathrm{HO}_{\mathrm{x}}{ }^{-}$and the $\mathrm{NO}_{\mathrm{y}}$-induced changes. This region should be further scrutinized during large SPEs to resolve these model $/$ measurement inconsistencies.

Measurements of $\mathrm{HO}_{\mathrm{x}}$ induced changes due to SPEs would be extremely useful to check our understanding of the mesospheric and upper stratospheric influences from the SPEs. Such $\mathrm{HO}_{\mathrm{x}}$ measurements would be particularly useful during the nighttime when other $\mathrm{HO}_{\mathrm{x}}$ production mechanisms are at a minimum [e.g., Brinksma et al., 2001]. It may be possible to measure the temperature influences of SPEs in the future, if the measurements have a precision of less than $1^{\circ} \mathrm{K}$. We anticipate further progress in our understanding of the influence of SPEs on constituents in the middle atmosphere in the next several years.

Acknowledgments. We thank NASA Headquarters Atmospheric Chemistry Modeling and Analysis Program for support during the time that this manuscript was written. The paper was improved by clarifications required to address topical editor John McCormack's and an anonymous referee's several good comments. We thank Judi Bordeaux, who provided assistance with scanning several of the other figures from various papers. We thank Steele Hill, who provided a publication quality image for Figure 1 .

\section{REFERENCES}

Banks, P. M., Joule heating in the high-latitude mesosphere, $J$. Geophys. Res., 84, 6709-6712, 1979.

Brinksma, E. J., Y. J. Meijer, I. S. McDermid, R. P. Cageao, J. B. Bergwerff, D. P. J. Swart, W. Ubachs, W. A. Matthews, W. Hogervorst, and J. W. Hovenier, First lidar observations of mesospheric hydroxyl, Geophys. Res. Lett., 25, 51-54, 1998.

Conway, R. R., M. E. Summers, M. H. Stevens, J. G. Cardon, P. Preusse, and D. Offermann, Satellite observations of upper stratospheric and mesospheric $\mathrm{OH}$ : the $\mathrm{HO}_{\mathrm{x}}$ dilemma, Geophys. Res. Lett., 27, 2613-2616, 2000.

Crutzen, P. J., I. S. A. Isaksen, and G. C. Reid, Solar proton events: Stratospheric sources of nitric oxide, Science, 189, 457-458 1975.

Fabian, P., J. A. Pyle, and R. J. Wells, The August 1972 solar proton event and the atmospheric ozone layer, Nature, 277, 458$460,1979$.

Forbush, S. E., Three unusual cosmic-ray increases possibly due to charged particles from the Sun, Phys. Rev., 70, 771-772, 1946.

Frederick, J. E., Solar corpuscular emission and neutral chemistry in the Earth's middle atmosphere, J. Geophys. Res., 81, 31793186, 1976.

Heath, D. F., A. J. Krueger, and P. J. Crutzen, Solar proton event: influence on stratospheric ozone, Science, 197, 886-889, 1977.

Jackman, C. H., J. E. Frederick, and R. S. Stolarski, Production of odd nitrogen in the stratosphere and mesosphere: An intercomparison of source strengths, J. Geophys. Res., 85, 7495-7505, 1980.

Jackman, C. H., and R. D. McPeters, The response of ozone to solar proton events during solar cycle 21: A theoretical interpretation, J. Geophys. Res., 90, 7955-7966, 1985

Jackman, C. H., and R. D. McPeters, Solar proton events as tests for the fidelity of middle atmosphere models, Physica Scripta, T18, 309-316, 1987

Jackman, C. H., A. R. Douglass, R. B. Rood, R. D. McPeters, and P. E. Meade, Effect of solar proton events on the middle atmosphere during the past two solar cycles as computed using a twodimensional model, J. Geophys. Res., 95, 7417-7428, 1990.

Jackman, C. H., J. E. Nielsen, D. J. Allen, M. C. Cerniglia, R. D. McPeters, A. R. Douglass, and R. B. Rood, The effects of the October 1989 solar proton events on the stratosphere as computed using a three-dimensional model, Geophys. Res. Lett., 20, 459-462, 1993.

Jackman, C. H., M. C. Cerniglia, J. E. Nielsen, D. J. Allen, J. M. Zawodny, R. D. McPeters, A. R. Douglass, J. E. Rosenfield, and R. B. Rood, Two-dimensional and three-dimensional model simulations, measurements, and interpretation of the influence of the October 1989 solar proton events on the middle atmosphere, J. Geophys. Res., 100, 11,641-11,660, 1995.

Jackman, C. H., E. L. Fleming, S. Chandra, D. B. Considine, and J. E. Rosenfield, Past, present and future modeled ozone trends with comparisons to observed trends, J. Geophys. Res., 101, 28,753-28,767, 1996

Jackman, C. H., E. L. Fleming, and F. M. Vitt, Influence of extremely large solar proton events in a changing stratosphere, J. Geophys. Res., 105, 11659-11670, 2000.

Jackman, C. H., R. D. McPeters, G. J. Labow, E. L. Fleming, C. J. Praderas, and J. M. Russell, Northern hemisphere atmospheric effects due to the July 2000 solar proton event, Geophys. Res. Lett., 28, 2883-2886, 2001.

Johnson, R. M., and J. G. Luhmann, Poker Flat MST radar observations of high latitude neutral winds at the mesopause during and after solar proton events, J. Atmos. Terr. Phys., 55, 12031218, 1993.

Maeda, K., and D. F. Heath, Stratospheric ozone response to a solar proton event: Hemispheric asymmetries, Pure Appl. Geophys., 119, 1-8, 1980/1981. 
Marin, D., and J. Lastovicka, Do solar flares affect total ozone?, Stud. Geophys. Geod. 42, 533-539, 1998.

McPeters, R. D., A nitric oxide increase observed following the July 1982 solar proton event, Geophys. Res. Lett., 13, 667-670, 1986.

McPeters, R. D., and C. H. Jackman, The response of ozone to solar proton events during solar cycle 21: the observations, $J$. Geophys. Res., 90, 7945-7954, 1985.

McPeters, R. D., C. H. Jackman, and E. G. Stassinopoulos, Observations of ozone depletion associated with solar proton events, J. Geophys. Res., 86, 12,071-12,081, 1981.

Porter, H. S., C. H. Jackman, and A. E. S. Green, Efficiencies for production of atomic nitrogen and oxygen by relativistic proton impact in air, J. Chem. Phys., 65, 154-167, 1976.

Randall, C. E., D. E. Siskind, and R. M. Bevilacqua, Stratospheric $\mathrm{NO}_{\mathrm{x}}$ enhancements in the southern hemisphere polar vortex in winter and spring of 2000, Geophys. Res. Lett, 28, 2385-2388, 2001.

Reagan, J. B., R. E. Meyerott, R. W. Nightingale, R. C. Gunton, R. G. Johnson, J. E. Evans, W. L. Imhof, D. F. Heath, and A. J. Krueger, Effects of the August 1972 solar particle events on stratospheric ozone, J. Geophys. Res., 86, 1473-1494, 1981.

Reid, G. C., Chapter 12 - Solar energetic particles and their effects on the terrestrial environment, in Physics of the Sun, Vol. III, edited by P. A. Sturrock, pp. 251-278, D. Reidel Publishing Company, 1986.

Reid, G. C., S. Solomon, and R. R. Garcia, Response of the middle atmosphere to the solar proton events of August-December 1989, Geophys. Res. Lett., 18, 1019-1022, 1991.

Roble, R. G., B. A. Emery, T. L. Killeen, G. C. Reid, S. Solomon, R. R. Garcia, D. S. Evans, G. R. Carignan, R. A. Heelis, W. B. Hanson, D. J. Winningham, N. W. Spencer, and L. H. Brace, Joule heating in the mesosphere and thermosphere during the July 13, 1982, solar proton event, J. Geophys. Res., 92, 60836090, 1987.

Rottger, J., Solar proton events: A source for long-period gravity waves in the polar mesosphere?, COSPAR Colloquia Series, Vol. 5, Solar Terrestrial Energy Program, 473-476, Proceedings 1992 STEP Symposium/ $5^{\text {th }}$ COSPAR Colloquium, Laurel, USA, 24-28 Aug. 1992, 1992.

Rusch, D. W., J.-C. Gerard, S. Solomon, P. J. Crutzen, and G. C. Reid, The effect of particle precipitation events on the neutral and ion chemistry of the middle atmosphere, 1, Odd nitrogen, Planet. Space Sci., 29, 767-774, 1981.
Solomon, S., and P. J. Crutzen, Analysis of the August 1972 solar proton event including chlorine chemistry, J. Geophys. Res., 86, 1140-1146, 1981.

Solomon, S., D. W. Rusch, J.-C. Gerard, G. C. Reid, and P. J. Crutzen, The effect of particle precipitation events on the neutral and ion chemistry of the middle atmosphere, 2, Odd hydrogen, Planet. Space Sci., 29, 885-892, 1981.

Solomon, S., G. C. Reid, D. W. Rusch, and R. J. Thomas, Mesospheric ozone depletion during the solar proton event of July 13, 1982, 2, Comparison between theory and measurements, Geophys. Res. Lett., 10, 257-260, 1983.

Swider, W., and T. J. Keneshea, Decrease of ozone and atomic oxygen in the lower mesosphere during a PCA event, Planet. Space Sci., 21, 1969-1973, 1973.

Swider, W., T. J. Keneshea, and C. I. Foley, An SPE disturbed Dregion model, Planet. Space Sci., 26, 883-892, 1978.

Thomas, R. J., C. A. Barth, G. J. Rottman, D. W. Rusch, G. H. Mount, G. M. Lawrence, R. W. Sanders, G. E. Thomas, and L. E. Clemens, Mesospheric ozone depletion during the solar proton event of July 13, 1982, 1, Measurments, Geophys. Res. Lett., 10, 257-260, 1983.

Vitt, F. M., and C. H. Jackman, A comparison of sources of odd nitrogen production from 1974 through 1993 in the Earth's middle atmosphere as calculated using a two-dimensional model, $J$. Geophys. Res., 101, 6729-6739, 1996.

Warneck, P., Cosmic radiation as a source of odd nitrogen in the stratosphere, J. Geophys. Res., 77, 6589-6591, 1972.

Weeks, L. H., R. S. CuiKay, and J. R. Corbin, Ozone measurements in the mesosphere during the solar proton event of 2 November 1969, J. Atmos. Sci., 29, 1138-1142, 1972.

World Meteorological Organization (WMO), Scientific Assessment of Ozone Depletion: 1998, Rep. 44, Global Ozone Res. And Monit. Proj., Geneva, 1999.

Zadorozhny, A. M., G. A. Tuchkov, V. N. Kikhtenko, J. Lastovicka, J. Boska, and A. Novak, Nitric oxide and lower ionosphere quantities during solar particle events of October 1989 after rocket and ground-based measurements, J. Atmos. Terr. Phys., 54, 183-192, 1992.

Charles H. Jackman and Richard D. McPeters, both at: Code 916, NASA Goddard Space Flight Center, Greenbelt, MD, 20771. 